\title{
Strong Enhancement of deSoot Activity of Transition Metal Oxides by Alkali Doping: Additive Effects of Potassium and Nitric Oxide
}

\author{
Piotr Legutko $^{1} \cdot$ Tomasz Jakubek $^{1} \cdot$ Wojciech Kaspera $^{1} \cdot$ Pawel Stelmachowski $^{1}$ \\ Zbigniew Sojka ${ }^{1} \cdot$ Andrzej Kotarba $^{1}$
}

Published online: 26 September 2016

(c) The Author(s) 2016. This article is published with open access at Springerlink.com

\begin{abstract}
A series of potassium-promoted spinels (Mn, Fe, $\mathrm{Co})$ were prepared with various $\mathrm{K}^{+}$promoter locations: on the surface (surface promotion) or in the bulk (formation of new layered and tunneled nanostructures via solid state reaction). All prepared samples were characterized by means of X-ray diffraction, Raman spectroscopy, X-ray fluorescence and $\mathrm{N}_{2}$-BET specific surface area analysis. Catalytic activity in soot combustion in different reaction conditions was investigated (tight contact, loose contact, loose contact with NO addition). It was shown that in all cases the nanostructuration is more effective than the surface promotion, with the layered structures of $\mathrm{KCo}_{4} \mathrm{O}_{8}$, $\mathrm{KMn}_{4} \mathrm{O}_{8}$ being the most catalytically active phases, lowering the soot combustion down to $250{ }^{\circ} \mathrm{C}$. The difference in activity between tight and loose contacts can be bridged in the presence of $\mathrm{NO}$ due to its transformation into $\mathrm{NO}_{2}$, which acts as the oxygen carrier from the catalyst surface into soot particles, eliminating the soot-catalyst contact difference.
\end{abstract}

Keywords Soot combustion - NO - Potassium promotion · Spinel $\cdot$ Nanostructuration

\section{Introduction}

During pyrolysis and the incomplete combustion of fuels (such as wood, coal, lignite or different fractions of petroleum) agglomerated soot particles of different carbon

Andrzej Kotarba

kotarba@chemia.uj.edu.pl

1 Faculty of Chemistry, Jagiellonian University, Ingardena 3, 30-060 Kraków, Poland forms are produced. They are one of the main components of particulate matter (PM). Long exposition of the human organism to PM leads to many illnesses like cardiovascular and lung diseases, heart attacks or arrhythmia. The nanometric size of the soot particles allows for their high penetration into the human body causing DNA code modifications that result in mutations and possible cancerogenic changes. Moreover, PM accumulation leads to atherosclerosis, antenatal complications, and respiratory system diseases. Deposition of PM, especially soot, on snow and ice, lowers its ability to reflect sunlight. The ice or snow, absorbing solar energy more readily, melts and in further effect has an impact on global warming [1].

The most important anthropogenic sources are coal combustion in electric plants and home heating systems, waste incineration, and car emissions-soot from fuel combustion and dust from tires wear. Since the main part of anthropogenic particulate matter is soot, it is an important task to decrease its emissions from diesel engines [1]. Many governments have introduced strict norms for pollutant emission [2]. These have led to the development of new technologies for soot emission reduction. It seems that catalytic diesel particulate filters (CDPF) are the most promising technology. DPFs can lower soot emission by up to $99 \%$ but soot accumulates inside them and regeneration is needed. Catalysts can regenerate DPFs in the temperature of exhaust gasses while a temperature of up to $600{ }^{\circ} \mathrm{C}$ is needed for regeneration without any catalyst [3, 4].

A lot of different groups of catalysts were investigated for soot combustion-noble metal-based, perovskites, spinels, ceria catalysts, chlorides, low melting point catalysts. The catalytically active phases were recently reviewed in $[3,5-8]$.

The alkali-containing systems form an interesting group of soot combustion catalysts. Alkali metals ( $\mathrm{Li}, \mathrm{Na}, \mathrm{K}, \mathrm{Rb}$, 
Cs) can be used as surface or bulk dopants in the metal oxide matrix. Surface promotion of $\mathrm{CeO}_{2}$ by a series of alkali metals showed that the catalytic activity depends both on the dopant nature and its concentration $[9,10]$. In [11] and [12] structural and surface alkali promotion of $\mathrm{SrTiO}_{3}$ was compared. The results showed that all dopants increased the activity with potassium promotion being the most effective. It was also shown that structural promotion was more effective than the surface one. Details concerning alkali promotion can be found in [13]. Systematic investigations of perovskite $\mathrm{K}_{\mathrm{x}} \mathrm{La}_{1-\mathrm{x}} \mathrm{FeO}_{3}$, spinels $\mathrm{A}_{2 \mathrm{x}} \mathrm{Cu}_{1-\mathrm{x}}$ $\mathrm{Fe}_{2} \mathrm{O}_{4}$ and $\mathrm{A}_{2 \mathrm{x}} \mathrm{Co}_{1-\mathrm{x}} \mathrm{Fe}_{2} \mathrm{O}_{4}$ (where $\mathrm{A}$ is an alkali metal) led to the conclusion that the most effective promoter is potassium and the activity depends on the promoter concentration. More comprehensive studies on the surface alkali promotion of d- and f-electron metal oxides such as cobalt, lanthanum, iron, chromium, manganese, niobium, vanadium, and cerium are presented in [14]. Examples of the use of mixed oxides (potassium bulk promotion) as catalysts include $\mathrm{K}_{6} \mathrm{Ti}_{4} \mathrm{O}_{11}, \mathrm{~K}_{2} \mathrm{Ti}_{2} \mathrm{O}_{5}, \mathrm{~K}_{2} \mathrm{Ti}_{4} \mathrm{O}_{9}$ [15], $\mathrm{KNbO}_{3}$ [16], $\mathrm{KFeO}_{2}$ and $\mathrm{K}_{2} \mathrm{Fe}_{22} \mathrm{O}_{34}$ [17] or $\mathrm{KVO}_{3}$ and $\mathrm{K}_{4} \mathrm{~V}_{2} \mathrm{O}_{7}$ [18]. Potassium containing glasses [19, 20] have also been found recently as a component of the most active soot combustion catalysts [21].

Since nitrogen oxides are present in diesel exhaust, their influence on catalytic activity in the soot oxidation process has been investigated. It was found that NO has a positive effect on catalyst activity in soot combustion as it forms $\mathrm{NO}_{2}$, which is a stronger oxidant for carbon particles than the oxygen [22]. A systematic shift of the temperature window of soot combustion on potassium-promoted spinels in the presence of NO was also reported [23]. It was found that potassium-containing catalysts can be used for the simultaneous removal of $\mathrm{NO}_{\mathrm{x}}$ and soot [24-26], so similar catalytic systems were also investigated in bench-scale experiments [26-28].

The aim of the study is to show how the doping of transition metal ( $\mathrm{Mn}, \mathrm{Fe}, \mathrm{Co}$ ) oxides by alkali facilitates the soot combustion process, by shifting the combustion temperature window below the target $400{ }^{\circ} \mathrm{C}$. This issue was addressed by systematic studies of catalytic activity in the soot combustion of a series of surface and structural potassium-promoted transition metal spinels in tight, loose contacts and various gas environments (with and without $\mathrm{NO}$ ).

\section{Experimental}

\subsection{Catalyst Preparation}

The surface doped catalysts were prepared by the wet impregnation of $1 \mathrm{~g}$ of the iron (Aldrich) and cobalt spinels (Fluka) with a potassium carbonate solution, to achieve the optimal alkali loading corresponding to the theoretical 0.5 monolayer, as described in [23]. The impregnated spinel was dried at $100^{\circ} \mathrm{C}$ for $1 \mathrm{~h}$ and subsequently calcined at $400{ }^{\circ} \mathrm{C}$ for $4 \mathrm{~h}$. These samples were further designated as $\mathrm{K} / \mathrm{Fe}_{3} \mathrm{O}_{4}$ and $\mathrm{K} / \mathrm{Co}_{3} \mathrm{O}_{4}$, respectively.

The samples of $\mathrm{K}_{2} \mathrm{Fe}_{22} \mathrm{O}_{34}$ ferrite were prepared by the solid-state reaction of a stoichiometric mixture of $\mathrm{K}_{2} \mathrm{CO}_{3}$ (POCh) with $\alpha-\mathrm{Fe}_{2} \mathrm{O}_{3}$ (Merck) at $1200{ }^{\circ} \mathrm{C}$ as described previously [29]. The $\mathrm{KFeO}_{2}$ sample was synthesized from $\mathrm{K}_{2} \mathrm{CO}_{3}$ with $\alpha-\mathrm{Fe}_{2} \mathrm{O}_{3}$ according to the procedure described in [30]. In brief, the mixtures of finely ground powders were placed in a porcelain crucible and heated at the rate of $5{ }^{\circ} \mathrm{C} / \mathrm{min}$ in the static air up to the final temperatures of $800{ }^{\circ} \mathrm{C}$ for $\mathrm{KFeO}_{2}$ and $1200{ }^{\circ} \mathrm{C}$ for $\mathrm{K}_{2} \mathrm{Fe}_{22} \mathrm{O}_{34}$.

The cryptomelane phase was prepared as described in [31]. The mass of $11 \mathrm{~g}$ of manganese(II) acetate was dissolved in $40 \mathrm{ml}$ of distilled water and $5 \mathrm{ml}$ of glacial acetic acid was added to achieve a $\mathrm{pH}=5$. The solution was heated and stirred under reflux for $30 \mathrm{~min} .6 .5 \mathrm{~g}$ of potassium permanganate was dissolved in $150 \mathrm{ml}$ of distilled water, then this solution was added to the previously prepared solution of $\mathrm{Mn}^{2+}$. The mixture was heated and stirred for $24 \mathrm{~h}$ under reflux. The solid residue was washed with water (for neutral $\mathrm{pH}$ ), dried overnight at $110{ }^{\circ} \mathrm{C}$, and calcined at $450{ }^{\circ} \mathrm{C}$ for $2 \mathrm{~h}$.

Birnessite was synthesized as described in [32]. A glucose solution $\left(1.4 \mathrm{~mol} / \mathrm{dm}^{3}\right)$ and $\mathrm{KMnO}_{4}$ solution $\left(0.27 \mathrm{~mol} / \mathrm{dm}^{3}\right)$ were mixed, with a glucose to $\mathrm{KMnO}_{4}$ molar ratio equal 1.5 . The solution was stirred at room temperature until a xerogel was formed. The xerogel was washed with water and dried at $110{ }^{\circ} \mathrm{C}$ overnight. The powder was calcined at $450{ }^{\circ} \mathrm{C}$ for $2 \mathrm{~h}$.

The cobalt oxide nanostructured by potassium $\left(\mathrm{KCo}_{4} \mathrm{O}_{8}\right)$ was prepared by grinding $2.13 \mathrm{~g}$ of the cobalt spinel with $1.1 \mathrm{~g}$ of potassium hydroxide ( $\mathrm{POCh})$. The produced powder was placed in a preheated oven and calcined at $700{ }^{\circ} \mathrm{C}$ for $12 \mathrm{~h}$. The pre-calcined bulk materials were placed in preheated ovens to avoid alkali loss due to thermal desorption, further compensated by the use of excessive amounts of alkali substrate (three times excess of potassium hydroxide). The synthesized bulk-doped sample was thoroughly washed with distilled water to remove excess potassium and ground in an agate mortar into a fine powder for further studies [33].

\subsection{Catalyst Characterization}

XRD patterns were recorded on a Rigaku MiniFlex powder diffractometer with $\mathrm{Cu} \mathrm{K} \alpha$ radiation, $2 \theta$ step scans of $0.02^{\circ}$ and a counting time of $1 \mathrm{~s}$ per step. The micro-Raman spectra were recorded under ambient conditions using a Renishaw InVia spectrometer equipped with a Leica DMLM confocal microscope and a CCD detector, with an 
excitation wavelength of $785 \mathrm{~nm}$. The laser power at the sample position was $1.5 \mathrm{~mW}(0.5 \%$ of total power $)$ with a magnification of $20 \times$. The Raman scattered light was collected in the spectral range of $150-800 \mathrm{~cm}^{-1}$. At least 6 scans, $10 \mathrm{~s}$ each, were accumulated to ensure a sufficient signal to noise ratio. For XRF analysis, ARL Quant'X spectrometer with Uniquant software, calibrated with metal standards series, was used. Specific surface area (SSA) was determined by three-point nitrogen adsorption/desorption with BET isotherm method with Quantasorb Junior (Quantachrome). The X-ray photoelectron spectra (XPS) of the catalyst samples were measured with a Prevac photoelectron spectrometer equipped with a hemispherical VG SCIENTA R3000 analyzer. The photoelectron spectra were measured using a monochromatized aluminum $\mathrm{AlK} \alpha$ source $(E=1486.6 \mathrm{eV})$. The base pressure in the analysis chamber during the measurements was $5 \times 10^{-9}$ mbar. Spectra were recorded with a constant pass energy of $100 \mathrm{eV}$ for the survey and narrow scan spectra. The binding energy scale was aligned with the main $\mathrm{C} 1 \mathrm{~s}$ band set to $295 \mathrm{eV}$.

\subsection{Soot Combustion Tests}

The activity in soot combustion of the catalysts was measured by means of TPO (temperature-programmed oxidation). The quartz fixed-bed reactor was heated $\left(10^{\circ} \mathrm{C} / \mathrm{min}\right)$ from RT to $750{ }^{\circ} \mathrm{C}$ while the concentrations of the released gases were measured by a quadrupole mass spectrometer (SRS RGA 200). Two gas mixtures were used in the tests: $5 \% \mathrm{O}_{2}$ in $\mathrm{He}$, as well as $3.3 \% \mathrm{O}_{2}, 0.3 \% \mathrm{NO}$ in $\mathrm{He}$, both at a $60 \mathrm{ml} / \mathrm{min}$ flow. The samples for the combustion test were prepared by weighing $0.05 \mathrm{~g}$ of soot (Degussa-Printex 80 , with the SSA of $230 \mathrm{~m}^{2} \mathrm{~g}^{-1}$ and average composition of $98 \%$ carbon and $1 \%$ oxygen, $1 \%$ of hydrogen, and other mineral components (of which $80 \%$ sulfur, $10 \%$ phosphorus and $10 \%$ potassium), examined by XRF and XPS) and the catalyst with an 8:1 ratio and then grinding them in a mortar for $10 \mathrm{~min}$ following the tight contact method or gently mixing in an Eppendorf tube following the loose contact protocol. The shifts of the temperature of $50 \%$ soot conversion $\left(\Delta T_{50}\right)$ was defined as $T_{50}$ for unpromoted spinel oxides minus $T_{50}$ for potassium-promoted samples. We also assessed the value of the reaction onset. For this purpose we used of the Arrhenius plot, assuming that $\mathrm{CO}_{2}$ concentration is proportional to the reaction rate constant (at the beginning of the reaction), and plot $\log \left(\mathrm{p}_{\mathrm{CO} 2} / \mathrm{Pa}\right)$ as a function of $T^{-1}$. On such Arrheniuslike plot the intercept between the line associated with the $p_{\mathrm{CO} 2}$ background and the line corresponding to $\mathrm{CO}_{2}$ evolution due to soot combustion reaction is taken as an indicator of the ignition temperature. We found this value to be independent on the amount of soot, thus more reliable than $T_{10}$, and take it as a measure of the reaction onset.

\section{Result and Discussion}

\subsection{Characterization}

The stoichiometry of all the investigated catalysts was assessed by XRF analysis (Table 1). An excess of potassium (observed also as potassium carbonate segregation on $\mathrm{XRD}$ results, see below) was confirmed in the birnessite and $\beta$-ferrite samples. The specific surface area of the investigated samples varied from 4 to $70 \mathrm{~m}^{2} / \mathrm{g}$. Separate catalytic experiments with the same phase composition (birnessite) with different specific surface areas showed no significant difference in their reactivity.

Diffraction patterns obtained for the investigated samples are shown in Fig. 1-manganese-based in Fig. 1a, iron-based in Fig. 1b, and cobalt-based in Fig. 1c. For all samples, the diffraction peaks were labeled with Miller indexes. The manganese catalysts, i.e., spinel, cryptomelane (tunneled structure), and birnessite (layered structure), were indexed in the Pmab (ICSD-30005 [34]), I4/m (ICSD59159 [35]) and $R \overline{3} m$ (ICSD-152290 [36]) space groups, respectively. Some reflections originating from an excess of potassium carbonate are only detectable in the case of the birnessite phase (marked with violet diamonds). Likewise, the iron catalysts were indexed, with the spinel (Pmc2 ${ }_{1}$ (ICSD-35002 [37]), $\beta$-ferrite $\mathrm{K}_{2} \mathrm{Fe}_{22} \mathrm{O}_{34}$ (tunneled structure) $\left(\mathrm{PC}_{3} / \mathrm{mmc}\right.$ (ICSD-83285 [29]) and monoferrite $\mathrm{KFeO}_{2}$ (layered structure), (Pbca (ICSD-94467 [38]) space groups. Some minor reflections from excess hematite $\alpha-\mathrm{Fe}_{2} \mathrm{O}_{3}$ are visible for the surface promoted and $\beta$-ferrite samples (marked with orange squares). The cobalt spinel $\mathrm{Co}_{3} \mathrm{O}_{4}$ was indexed in the $F d \overline{3} m$ (ICSD-150805 [39]) space group. Potassium cobaltate $\mathrm{KCo}_{4} \mathrm{O}_{8}$ (tunneled structure) was indexed in the $R 3 \mathrm{~m}$ space group (ICSD-89454 [40]).

Table 1 Actual formulas from XRF analysis and specific surface areas (SSA) of the investigated samples

\begin{tabular}{lll}
\hline & Formula from XRF & SSA $\left(\mathrm{m}^{2} \mathrm{~g}^{-1}\right)$ \\
\hline $\mathrm{Mn}_{3} \mathrm{O}_{4}$ & - & 6 \\
$\mathrm{KMn}_{8} \mathrm{O}_{16}$ & $\mathrm{~K}_{0.93} \mathrm{Mn}_{8} \mathrm{O}_{16}$ & 70 \\
$\mathrm{KMn}_{4} \mathrm{O}_{8}$ & $\mathrm{~K}_{1.28} \mathrm{Mn}_{4} \mathrm{O}_{8}$ & 5.6 \\
$\mathrm{Fe}_{3} \mathrm{O}_{4}$ & - & 35 \\
$\mathrm{~K}_{2} \mathrm{Fe}_{22} \mathrm{O}_{34}$ & $\mathrm{~K}_{2.08} \mathrm{Fe}_{22} \mathrm{O}_{34}$ & 4 \\
$\mathrm{KFeO}_{2}$ & $\mathrm{~K}_{0.94} \mathrm{FeO}_{2}$ & 17 \\
$\mathrm{Co}_{3} \mathrm{O}_{4}$ & - & 16 \\
$\mathrm{KCo}_{4} \mathrm{O}_{8}$ & $\mathrm{~K}_{0.76} \mathrm{Co}_{4} \mathrm{O}_{8}$ & 5 \\
\hline
\end{tabular}



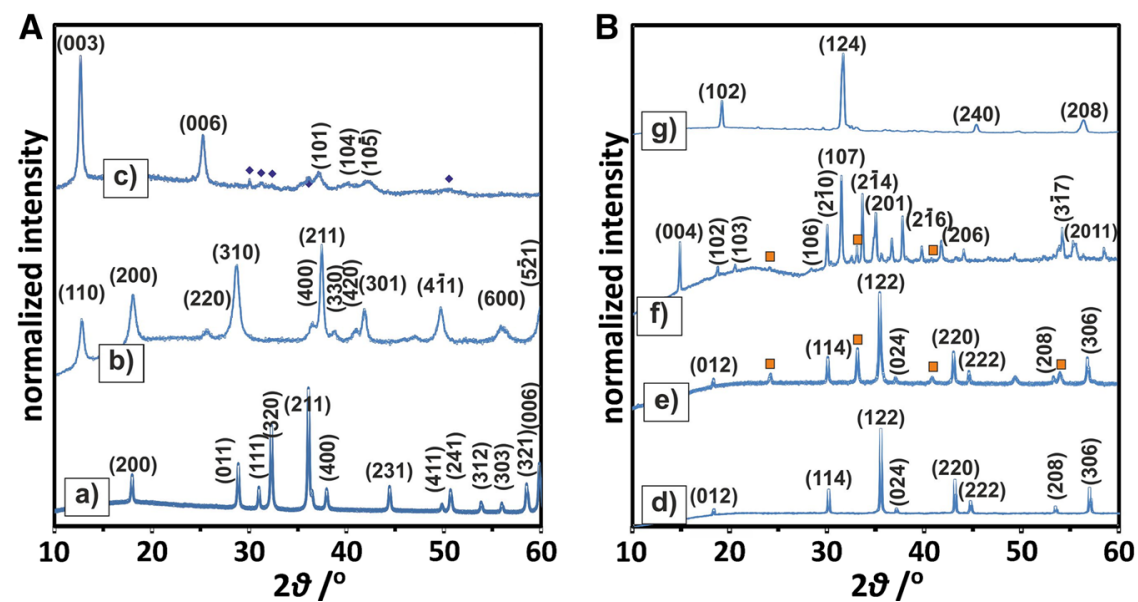

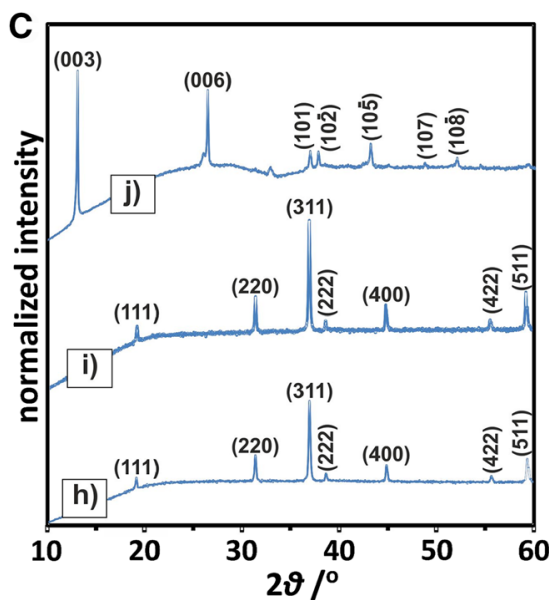

Fig. 1 Diffraction patterns of manganese-based (a), iron-based (b) and cobalt-based (c) catalysts. Manganese spinel $\mathrm{Mn}_{3} \mathrm{O}_{4}$ (a), cryptomelane $\mathrm{KMn}_{8} \mathrm{O}_{16}\left(\right.$ b), birnessite $\mathrm{KMn}_{4} \mathrm{O}_{8}(\mathbf{c})$, iron spinel $\mathrm{Fe}_{3} \mathrm{O}_{4}$ (d), potassium-doped $\mathrm{Fe}_{3} \mathrm{O}_{4}(\mathbf{e}), \beta$-ferrite $\mathrm{K}_{2} \mathrm{Fe}_{22} \mathrm{O}_{34}$ (f), monoferrite

Raman spectra obtained for investigated samples were shown in Fig. 2-manganese-based in Fig. 2a, iron-based in Fig. 2b, and cobalt-based in Fig. 2c. Where possible the symmetry was assigned based on the supporting literature. The $\mathrm{Mn}_{3} \mathrm{O}_{4}$ spectra showed six visible bands: 175, 289, 318, 374, 477, and $658 \mathrm{~cm}^{-1}$ [41]. Bands at 186, 285, 393, $479,514,582,639$ and $750 \mathrm{~cm}^{-1}$ were visible on the cryptomelane spectra [42]. On the birnessite spectra, bands at $280,409,477,506,577,634$ and $728 \mathrm{~cm}^{-1}$ are present. The same bands were observed in [43].

The iron spinel $\mathrm{Fe}_{3} \mathrm{O}_{4}$ spectrum shows three visible bands: 304,541 and $665 \mathrm{~cm}^{-1}$ [44]. In the potassium doped $\mathrm{Fe}_{3} \mathrm{O}_{4}$ spectrum, some additional peaks (marked with orange squares) were assigned to hematite, formed
$\mathrm{KFeO}_{2}(\mathbf{g})$, cobalt spinel $\mathrm{Co}_{3} \mathrm{O}_{4}(\mathbf{h})$, potassium-doped $\mathrm{Co}_{3} \mathrm{O}_{4}$ (i), potassium cobaltate $\mathrm{KCo}_{4} \mathrm{O}_{8}(\mathbf{j})$. Hematite $\mathrm{Fe}_{2} \mathrm{O}_{3}$ phase is marked by orange squares

during calcination. On the other hand potassium $\beta$-ferrite displays rich Raman spectrum. There is no literature concerning this material, but using detailed studies on $\mathrm{BaFe}_{12} \mathrm{O}_{19}$ spectrum, based on the vibrations of $\beta$-alumina (isostructural with $\beta$-ferrite) and other ferrites described in [45], allowed for some interpretation. The most intensive band, observed at $414 \mathrm{~cm}^{-1}$, was assigned to the vibration of the octahedral group $\mathrm{FeO}_{6}$ in the $A_{1 \mathrm{~g}}$ symmetry, as were the intensive bands at 517 and $618 \mathrm{~cm}^{-1}$ and the less intensive bands at 445 and $489 \mathrm{~cm}^{-1}$. Relatively intensive peaks at 680 and $719 \mathrm{~cm}^{-1}$ were assigned to the vibrations of the $\mathrm{FeO}_{5}$ bipyramid and $\mathrm{FeO}_{4}$ tetrahedral group, respectively, both in the $A_{1 \mathrm{~g}}$ symmetry. The less intensive band at $221 \mathrm{~cm}^{-1}$ was assigned to vibrations of the $\mathrm{O}-\mathrm{Fe}-$
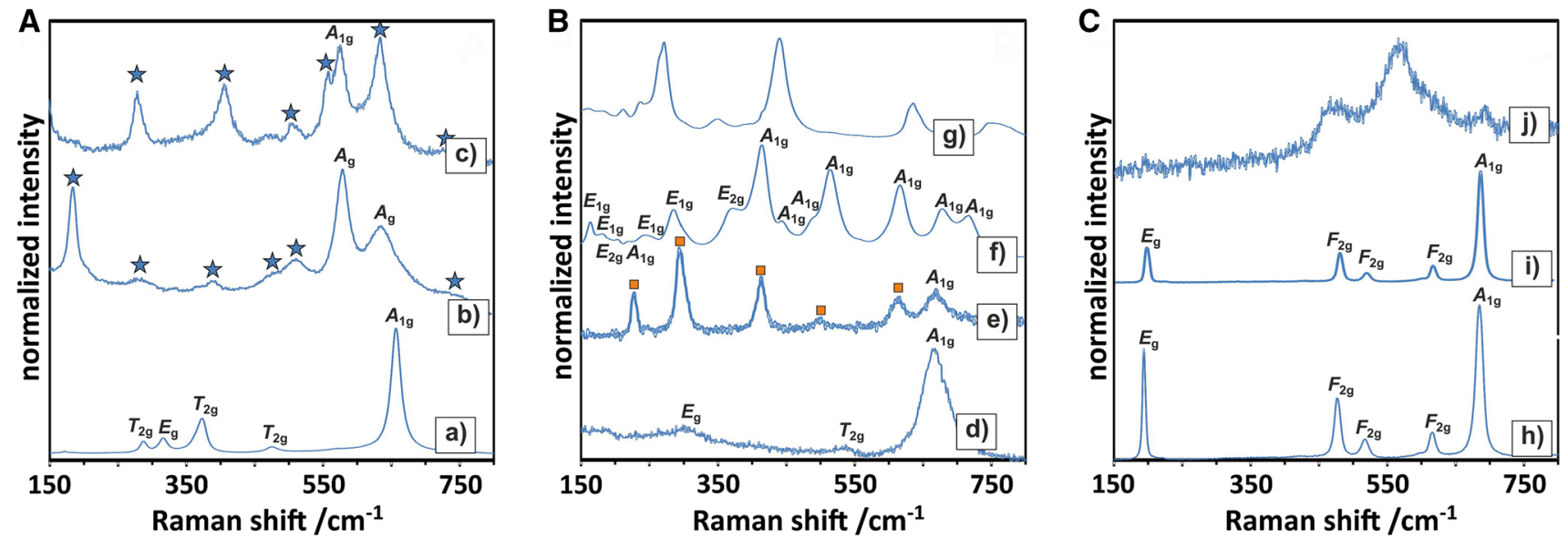

Fig. 2 Raman spectra of manganese-based (a), iron-based (b) and cobalt-based (c) catalysts. Manganese spinel $\mathrm{Mn}_{3} \mathrm{O}_{4}$ (a), cryptomelane $\mathrm{KMn}_{8} \mathrm{O}_{16}(\mathbf{b})$, birnessite $\mathrm{KMn}_{4} \mathrm{O}_{8}(\mathbf{c})$, iron spinel $\mathrm{Fe}_{3} \mathrm{O}_{4}$ (d), potassium-doped $\mathrm{Fe}_{3} \mathrm{O}_{4}(\mathbf{e}), \quad \beta$-ferrite $\mathrm{K}_{2} \mathrm{Fe}_{22} \mathrm{O}_{34}$ (f), monoferrite $\mathrm{KFeO}_{2}(\mathbf{g})$, cobalt spinel $\mathrm{Co}_{3} \mathrm{O}_{4}(\mathbf{h})$, potassium-doped $\mathrm{Co}_{3} \mathrm{O}_{4}$ (i), potassium cobaltate $\mathrm{KCo}_{4} \mathrm{O}_{8}$ (j). Fingerprints without assigned symmetry are marked by blue stars (for $\mathrm{KFeO}_{2}, \mathrm{~K}_{2} \mathrm{Fe}_{22} \mathrm{O}_{34}$ Raman spectra are reported for the first time in the literature). Hematite $\alpha-\mathrm{Fe}_{2} \mathrm{O}_{3}$ phase is marked by orange squares 
$\mathrm{O}$ bridge in the $A_{1 \mathrm{~g}}$ symmetry. Relatively intensive and less intensive bands at 166 and $185 \mathrm{~cm}^{-1}$ were assigned to vibrations of spinel blocks in $E_{1 \mathrm{~g}}$. The rest of the bands were not assigned to specific vibrations but symmetry can be assigned to-206 $\mathrm{cm}^{-1}\left(E_{2 \mathrm{~g}}\right), 245 \mathrm{~cm}^{-1}\left(E_{1 \mathrm{~g}}\right), 288 \mathrm{~cm}^{-1}$ $\left(E_{1 \mathrm{~g}}\right)$ and $373 \mathrm{~cm}^{-1}\left(E_{2 \mathrm{~g}}\right)$ Potassium monoferrite spectra had fewer peaks than the $\beta$-ferrite spectra. It was related to a higher symmetry of the $\mathrm{KFeO}_{2}$ primitive cell than that of $\mathrm{K}_{2} \mathrm{Fe}_{22} \mathrm{O}_{34}$. This spectrum was different from other simple and mixed iron oxides so it can be used for identification but the lack of literature on this material prevented vibration assignment.

The $\mathrm{Co}_{3} \mathrm{O}_{4}$ spectrum displayed five bands: 193, 476, 518,617 and $685 \mathrm{~cm}^{-1}$ [46]. No additional peaks were visible on potassium-doped $\mathrm{Co}_{3} \mathrm{O}_{4}$ Raman spectrum. On the $\mathrm{KCo}_{4} \mathrm{O}_{8}$ spectrum, three broad bands were visible: 464 , 575 , and $695 \mathrm{~cm}^{-1}$

Binding energies for $\mathrm{K} 2 \mathrm{p}_{3 / 2}, \mathrm{O}$ 1s and $2 \mathrm{p}_{3 / 2}$ maxima for transition metals are summarized in Table 2. In the case of birnessite and cryptomelane peaks assigned to both Mn(III) and $\mathrm{Mn}(\mathrm{IV})$ were clearly visible and shifted to higher energies due to potassium promotion. In the case of $\mathrm{Fe}$ based samples, potassium promotion led to an increase in the iron binding energy. As described in [48] it is connected with the increase of $\mathrm{Fe}$ (III) content. The shift in Co $2 \mathrm{p}_{3 / 2}$ peak position to a higher energy can be interpreted as an increase in the Co(IV) content, as discussed in [33]. The highest differences between the binding energies of $\mathrm{K} 2 \mathrm{p}_{3 / 2}$ for surface and bulk promotion were seen for Fe-based samples 1.1-1.3 eV, whereas for Co-based catalysts it was only $0.3 \mathrm{eV}$. It showed a remarkable difference of the potassium state on the surface and in the bulk of the iron oxide matrix, whereas the difference in the case of the cobalt-oxide matrix is much lower. The difference of potassium binding energy between the tunneled cryptomelane and layered birnessite phases is $0.7 \mathrm{eV}$, whereas for the tunneled monoferrite and layered $\beta$-ferrite it is only $0.1-0.3 \mathrm{eV}$. Oxygen $1 \mathrm{~s}$ peak energy was slightly increased in the case of $\mathrm{Mn}$ - and Co-based samples, whereas for $\mathrm{Fe}$ based samples the observed shift was much higher.

In summary, the performed characterization of the obtained materials revealed that the catalysts stoichiometry was close to the assumed. The samples are essentially monophasic-surface promotion did not alter the diffraction patterns-whereas for bulk promoted samples the presence of minor spurious phases undetectable by XRD was also excluded by the locally more sensitive Raman probe. For all surface promoted materials the XPS analysis confirmed the presence of potassium. The surface or bulk (nano-structuration) location of the promoter was confirmed in the case of iron and cobalt. For the manganese spinel, due to a very low temperature of intercalation, nanostructured phases alone were observed [49].

\subsection{Catalytic Activity}

Detailed investigations of catalytic activity in different reaction conditions of the investigated samples were performed and the results are shown in Fig. 3 for tight contact, loose contact and loose contact with NO addition. As a reference, a conversion curve of the non-catalytic soot combustion is also presented (dotted line). The arrows represent the promotional effect as a shift of the conversion curves towards lower temperature around the $T_{50}$. The results clearly reveal that the soot combustion progress depends strongly on both the contact mode and also the type of transition metal and potassium location (bulk or surface), as well as the presence of NO.
Table 2 XPS binding energies for $\mathrm{K} 2 \mathrm{p}, \mathrm{O} 1 \mathrm{~s}$ and transition metal (Mn 2p $\mathrm{p}_{3 / 2}$, Fe 2 $\mathrm{p}_{3 / 2}$, Co $2 p_{3 / 2}$ ) in the synthesized samples (this work) and the parent spinels (literature references)

\begin{tabular}{llll}
\hline Sample & \multicolumn{2}{l}{ Binding energy/eV } & \\
\cline { 2 - 4 } & $\mathrm{K} 2 \mathrm{p}_{3 / 2}$ & Transition metal & $\mathrm{O} 1 \mathrm{~s}$ \\
\hline $\mathrm{Mn}_{3} \mathrm{O}_{4}$ & - & $\mathrm{Mn} 2 \mathrm{p}_{3 / 2}$ & \\
$\mathrm{KMn}_{4} \mathrm{O}_{8}$ & 293 & 641.2 & $530.6[47]$ \\
$\mathrm{KMn}_{8} \mathrm{O}_{16}$ & 292.3 & $641.6\left(\mathrm{Mn}^{3+}\right), 642.9\left(\mathrm{Mn}^{4+}\right)$ & $529.9,531.8,533.0$ \\
$\mathrm{Fe}_{3} \mathrm{O}_{4}$ & & $644.1,642.6$ & $530.1,530.6,531.1$ \\
$\mathrm{~K} / \mathrm{Fe}_{3} \mathrm{O}_{4}$ & - & $\mathrm{Fe} 2 \mathrm{p}_{3 / 2}$ & \\
$\mathrm{~K}_{2} \mathrm{Fe}_{22} \mathrm{O}_{34}$ & 293.6 & 709.0 & $528.3,529.6[48]$ \\
$\mathrm{KFeO}_{2}$ & 292.5 & 712.1 & $532.3,530.1$ \\
$\mathrm{Co}_{3} \mathrm{O}_{4}$ & $292.2-292.4$ & 710.3 & 529.6 \\
$\mathrm{~K}_{\mathrm{Co}_{3} \mathrm{O}_{4}}$ & & $709.7-710.0$ & $530.4-530.8$ \\
$\mathrm{KCo}_{4} \mathrm{O}_{8}$ & 292.7 & $\mathrm{Co} 2 \mathrm{p}_{3 / 2}$ & \\
\hline
\end{tabular}



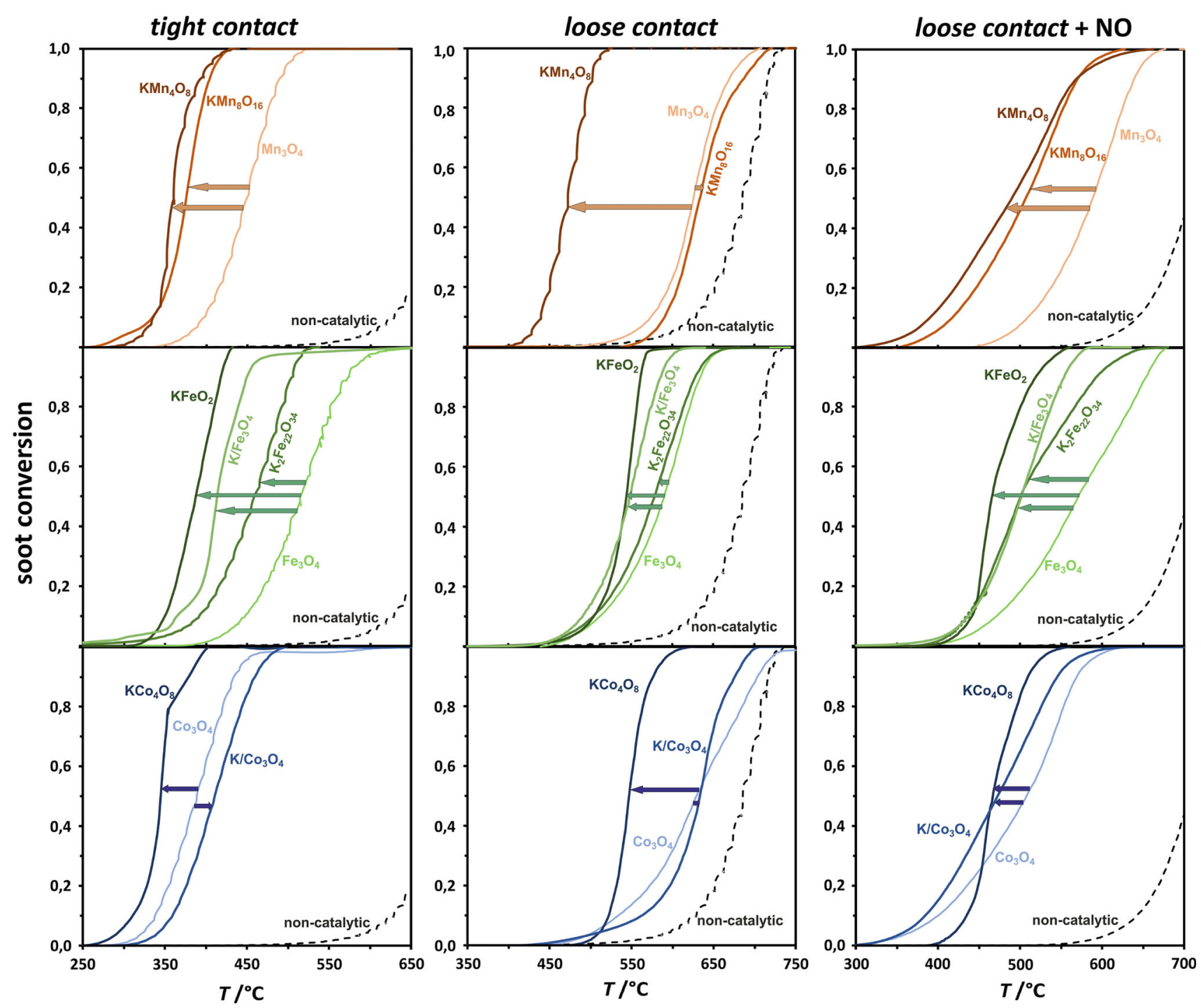

Fig. 3 Soot combustion tests on manganese, iron and cobalt spinels unpromoted and promoted surficial and structural by potassium in different reaction conditions-tight contact, loose contact, loose contact with $\mathrm{NO}$ addition

In the tight contact mode, the most active phases were potassium cobaltate $\left(\mathrm{KCo}_{4} \mathrm{O}_{8}\right)$, birnessite $\left(\mathrm{KMn}_{4} \mathrm{O}_{8}\right)$ and monoferrite $\left(\mathrm{KFeO}_{2}\right)$ - the temperature of $50 \%$ conversion $\left(T_{50}\right)$ of soot were shifted by about 45,90 , and $130{ }^{\circ} \mathrm{C}$, respectively, in comparison to the unpromoted spinels.

Surface potassium promotion is beneficial for soot combustion, however, only in the case of iron $\left(\Delta T_{50} \sim 105^{\circ} \mathrm{C}\right)$, while for cobalt it has a slightly negative effect $\left(\Delta T_{50} \sim-20{ }^{\circ} \mathrm{C}\right)$. A proposed explanation for these observations is the different interaction with oxygen. Whereas magnetite is readily oxidized into the corresponding sesquioxide $\left(\gamma-\mathrm{Fe}_{2} \mathrm{O}_{3} / \alpha-\mathrm{Fe}_{2} \mathrm{O}_{3}\right)$ in the reaction conditions, cobalt spinel is oxidation resistant [50]. The interaction of the unpromoted $\mathrm{Co}_{3} \mathrm{O}_{4}$ with oxygen leads to the formation of surface oxygen species, which participate in the soot oxidation. However, the presence of potassium leads to facile recombination of the surface oxygen species reducing their availability in the course of soot combustion [33]. The highest activity is exhibited by $\mathrm{KCo}_{4} \mathrm{O}_{8}$, and $\mathrm{KMn}_{4} \mathrm{O}_{8}$ catalysts which lower down the reaction onset (determined from Arrhenius-like plot) to 255 and $250{ }^{\circ} \mathrm{C}$, respectively, in comparison to non-catalytic soot combustion, beginning above $550{ }^{\circ} \mathrm{C}$.

Summarizing, for all the investigated catalyst potassium promotion has a dramatic effect on catalytic activity, and the best results were observed for bulk promotion in each case. The highest activity is exhibited by $\mathrm{KCo}_{4} \mathrm{O}_{8}$, and $\mathrm{KMn}_{4} \mathrm{O}_{8}$ catalysts, which lower the onset of the soot oxidation down to the spectacular value of $\sim 250{ }^{\circ} \mathrm{C}$.

In the loose contact mode the reaction, as expected, shifts to much higher temperatures (by $\sim 150{ }^{\circ} \mathrm{C}$ ), but the observed changes are not that regular as those in the tight 
contact mode. The most active phases were the same as in tight contact mode: $\mathrm{KMn}_{4} \mathrm{O}_{8}, \mathrm{KFeO}_{2}$, and $\mathrm{KCo}_{4} \mathrm{O}_{8}$. In the case of the manganese-based samples, the largest activity increase for the $\mathrm{KMn}_{4} \mathrm{O}_{8}$ catalyst was revealed $\left(\Delta T_{50} \sim 150{ }^{\circ} \mathrm{C}\right)$. Surprisingly, the second structurally promoted sample $\left(\mathrm{KMn}_{8} \mathrm{O}_{16}\right)$ was less active than the unpromoted manganese spinel $\left(\Delta T_{50} \sim-10{ }^{\circ} \mathrm{C}\right)$, in contrast to the tight contact mode. Only for iron catalyst the activity sequence $\mathrm{KFeO}_{2}>\mathrm{K} / \mathrm{Fe}_{3} \mathrm{O}_{4}>\mathrm{K}_{2} \mathrm{Fe}_{22} \mathrm{O}_{34}>$ $\mathrm{Fe}_{3} \mathrm{O}_{4} / \mathrm{Fe}_{2} \mathrm{O}_{3}$ is univocally preserved, though the differences are much smaller.

In the loose contact mode, the presence of NO in the gas mixture leads to the substantial decrease in the reaction temperature, making the situation quite similar to that observed for the tight contact mode measurements. In these conditions the characteristics of the conversion curves are different from those of tight and loose contact conditionsthey exhibit a smaller slope, implying a lower activation energy for the reaction. The most striking observation was that for all the samples potassium promotion of bare spinel oxides decreased the $T_{50}$ for the same values as in the tight contact conditions. The only exception was the surfacepromoted cobalt spinel, which had a lower activity than the unpromoted spinel in tight contact conditions, and in loose contact with NO addition became the most active.

The shifts of the temperature of $50 \%$ of soot conversion for all investigated samples are collected in Fig. 4. Inspection of the presented results clearly shows that the potassium promotional effects (shift in $\Delta T_{50}$ values with respect to the parent spinels) are strikingly similar to the tight contact conditions and the loose contact with NO addition. At the same time, they are dramatically different from the results obtained in the loose contact mode. This indicates that the loss of the mutual contact between the catalyst surface and the soot particles upon passing from tight to loose contact can be to a large extent compensated in the presence of NO. It may be accounted for by the crucial role of surface mobility of oxygen species in soot oxidation $[3,7]$.

In the case of mobile surface oxygen species, the number of direct soot-catalyst contact is of less importance that for rigid oxygen. Indeed, spillover of mobile reactive oxygen species allows for oxidation of remote soot particles, whereas for immobile species their direct contact with the soot particles is required. This effect implies a large difference between tight and loose contact as observed in the case of e.g., $\mathrm{Mn}_{3} \mathrm{O}_{4}$ (immobile surface oxygen) and a smaller effect for $\mathrm{KMn}_{4} \mathrm{O}_{8}$ (mobile surface oxygen). As reported in detailed investigations, in the catalytic cycle of soot combustion $\mathrm{NO}$ can be oxidized to $\mathrm{NO}_{2}$, which in turn oxidizes soot more effectively [51, 52]. In such cases, it can be supposed that NO is preferentially oxidized on the investigated catalysts, transferring effectively the catalyst generated oxygen species into the soot particles. Thus, the difference in contact between soot and the catalyst resulting from the different mixing of the solids is substantially attenuated since the $\mathrm{NO} / \mathrm{NO}_{2}$ couple acts as an oxygen carrier. Such a role of $\mathrm{NO}_{2}$ as an oxygen carrier has also been reported in the case of $\mathrm{deNO}_{\mathrm{x}}$ reactions over metalozeolites [53].

Summarizing, for $\mathrm{Mn}$, Fe spinels the potassium promotion leads to pronounced enhancement in soot combustion activity in tight and loose contacts, however, for Co spinel the bulk promotion is positive, whereas surface promotion is slightly inhibitive. In all the investigated cases the nanostructuration of the parent spinel into the layered or tunneled structures results in the best catalytic performance. The difference in activity between tight and
A

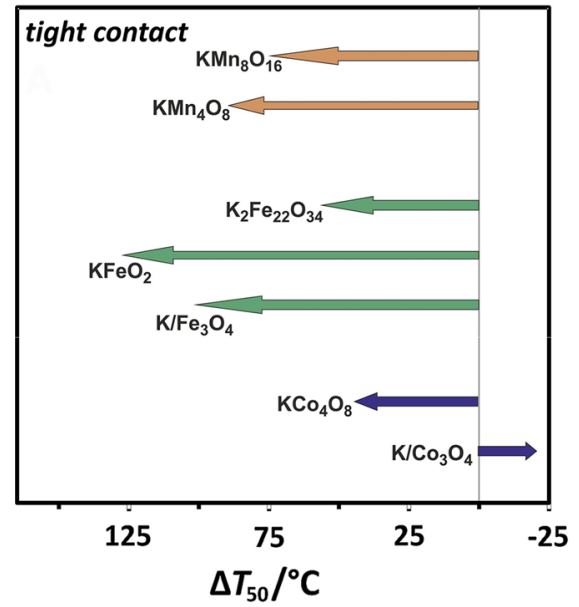

B

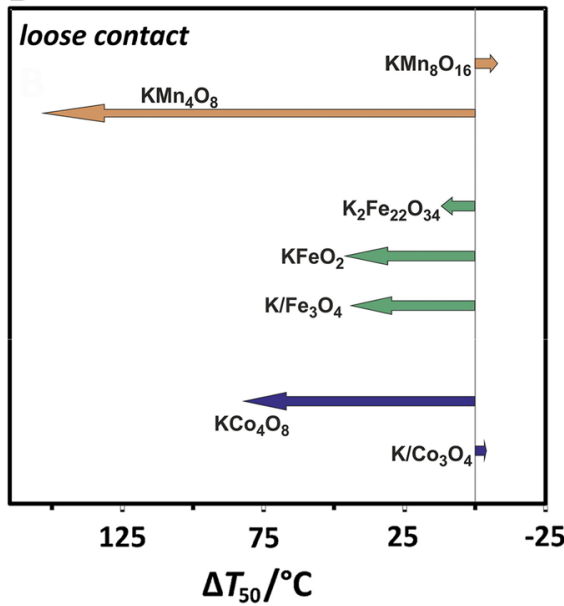

C

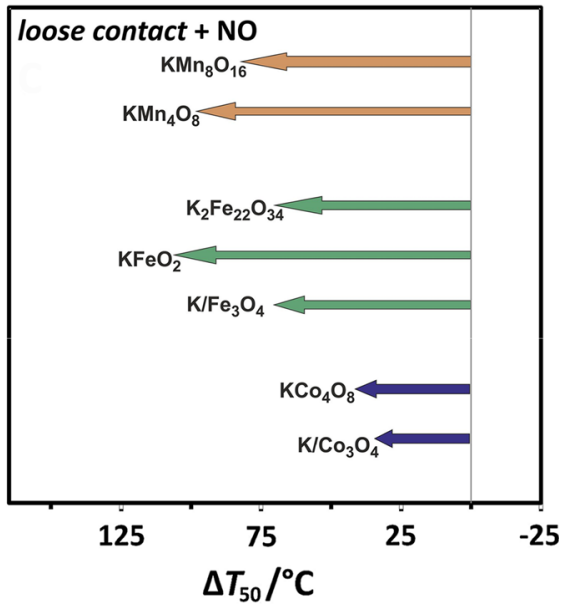

Fig. 4 Temperature shifts in soot combustion process caused by structural or surface potassium promotion of manganese, iron and cobalt spinels in tight contact $(\mathbf{a})$, loose contact $(\mathbf{b})$, loose contact and $\mathrm{NO}$ conditions (c) 
loose contacts can be bridged in the presence of NO in the feed due to its transformation into $\mathrm{NO}_{2}$, which acts as the oxygen carrier from the catalyst surface $\left(\mathrm{NO}+\mathrm{O}_{\text {surf }} \rightarrow\right.$ $\mathrm{NO}_{2}$ ) into soot particles $\left(\mathrm{NO}_{2}+\mathrm{C} \rightarrow \mathrm{CO}_{2}+\mathrm{N}_{2}\right)$.

\section{Conclusions}

The paper presents systematic studies of the promotional effect of potassium on the activity of transition metal (Mn, $\mathrm{Fe}, \mathrm{Co})$ spinels in catalytic soot combustion. The research presented in the paper reveals, that potassium addition can substantially improve the spinel activity in soot combustion, however, the effect strongly depends in each case on the promoter concentration but also on its location (bulk or surface). It was shown that the bulk promotion is more effective than the surface, with the layered structures of $\mathrm{KCo}_{4} \mathrm{O}_{8}, \mathrm{KMn}_{4} \mathrm{O}_{8}$ being the most active phases, which lower the onset of the soot oxidation down to the spectacular value of $\sim 250{ }^{\circ} \mathrm{C}$. The difference in activity between tight and loose contacts can be bridged in the presence of $\mathrm{NO}$ due to its transformation into $\mathrm{NO}_{2}$, which acts as the oxygen carrier from the catalyst surface into soot particles, eliminating the soot-catalyst contact difference.

Acknowledgments The project was financed by the Polish National Science Center awarded by decision number DEC-2011/01/B/ST4/ 00574. Piotr Legutko received funding for the preparation of his doctoral dissertation from the Polish National Science Center under the doctoral scholarship funding program based on the decision number DEC-2014/12/T/ST4/00687. This research was partially carried out using the equipment purchased thanks to the financial support of the European Regional Development Fund in the framework of the Polish Innovation Economy Operational Program (contract no. POIG.02.01.00-12-023/08).

Open Access This article is distributed under the terms of the Creative Commons Attribution 4.0 International License (http://crea tivecommons.org/licenses/by/4.0/), which permits unrestricted use, distribution, and reproduction in any medium, provided you give appropriate credit to the original author(s) and the source, provide a link to the Creative Commons license, and indicate if changes were made.

\section{References}

1. EEA (2014) Air quality in Europe-2014 report. European Environment Agency, Copenhagen

2. Johnson T (2008) Diesel emission control in review. SAE Tech Pap 1:69-81

3. Fino D (2007) Diesel emission control: catalytic filters for particulate removal. Sci Tech Adv Mater 8:93-100

4. Caroca J, Villata G, Fino D, Russo N (2009) Comparison of different diesel particulate filters. Top Catal 52:2076-2082

5. Van Setten BAAL, Makkee M, Moulijn JA (2001) Science and technology of catalytic diesel particulate filters. Catal Rev 43:489-564
6. Bueno-López A (2014) Diesel soot combustion ceria catalysts. Appl Catal B 146:1-11

7. Stanmore BR, Brilhac JF, Gilot P (2001) The oxidation of soot: a review of experiments, mechanisms and models. Carbon 39:2247-2268

8. Hernández-Giménez AM, Castelló DL, Bueno-López A (2014) Diesel soot combustion catalysts: review of active phases. Chem Pap 68:1154-1168

9. Aneggi E, de Leitenburg C, Dolcetti G, Trovarelli A (2008) Diesel soot combustion activity of ceria promoted with alkali metals. Catal Today 136:3-10

10. Legutko P, Kaspera W, Stelmachowski P, Sojka Z, Kotarba A (2014) Boosting the catalytic activity of magnetite in soot oxidation by surface alkali promotion. Catal Commun 56:139-142

11. Ura B, Trawczyński J, Kotarba A, Bieniasz W, Illan-Gomez MJ, Bueno-López A, López-Suárez FE (2011) Effect of potassium addition on catalytic activity of $\mathrm{SrTiO}_{3}$ catalyst for diesel soot combustion. Appl Catal B 101:169-175

12. López-Suárez FE, Bueno-López A, Illán-Gómez MJ, Ura B, Trawczynski J (2009) Potassium stability in soot combustion perovskite catalysts. Top Catal 52:2097-2100

13. An H, Kilroy C, McGinn PJ (2004) Combinatorial synthesis and characterization of alkali metal doped oxides for diesel soot combustion. Catal Today 98:423-429

14. An HM, McGinn PJ (2006) Catalytic behavior of potassium containing compounds for diesel soot combustion. Appl Catal B 62:46-56

15. Meng X, Wang Q, Duan L, Chung J-S (2012) Catalytic combustion of diesel soot over perovskite-type catalyst: Potassium titanates. Kinet Catal 53:560-564

16. Pecchi G, Cabrera B, Delgado EJ, García X, Jimenez R (2013) Activity of $\mathrm{KNbO}_{3}$ as catalyst for soot combustion: Effect of the preparation method. Appl Catal A 453:341-348

17. Legutko P, Stelmachowski P, Trębala M, Sojka Z, Kotarba A (2013) Role of electronic factor in soot oxidation process over tunnelled and layered potassium iron oxide catalysts. Top Catal 56:489-492

18. Saracco G, Badini C, Russo N, Specchia V (1999) Development of catalysts based on pyrovanadates for diesel soot combustion. Appl Catal B 21:233-242

19. An H, Su C, McGinn PJ (2009) Application of potash glass as a catalyst for diesel soot oxidation. Catal Commun 10:509512

20. Su C, McGinn PJ (2013) The effect of $\mathrm{Ca}^{2+}$ and $\mathrm{Al}^{3+}$ additions on the stability of potassium disilicate glass as a soot oxidation catalyst. Appl Catal B 138-139:70-78

21. Su C, McGinn PJ (2014) Application of glass soot catalysts on metal supports to achieve low soot oxidation temperature. Catal Commun 43:1-5

22. Kumar PA, Tanwar MD, Russo N, Pirone R, Fino D (2012) Synthesis and catalytic properties of $\mathrm{CeO}_{2}$ and $\mathrm{Co} / \mathrm{CeO}_{2}$ nanofibres for diesel soot combustion. Catal Today 184:279-287

23. Legutko P, Kaspera W, Jakubek T, Stelmachowski P, Kotarba A (2013) Influence of potassium and NO addition on catalytic activity in soot combustion and surface properties of iron and manganese spinels. Top Catal 56:745-749

24. Matarrese R, Castoldi L, Lietti L, Forzatti P (2007) High performances of $\mathrm{Pt}-\mathrm{K} / \mathrm{Al}_{2} \mathrm{O}_{3}$ versus $\mathrm{Pt}-\mathrm{Ba} / \mathrm{Al}_{2} \mathrm{O}_{3} \mathrm{LNT}$ catalysts in the simultaneous removal of $\mathrm{NO}_{\mathrm{x}}$ and soot. Top Catal 42:293-297

25. Matarrese R, Castoldi L, Lietti L, Forzatti P (2009) Simultaneous Removal of $\mathrm{NO}_{\mathrm{x}}$ and Soot Over Pt-Ba/ $/ \mathrm{Al}_{2} \mathrm{O}_{3}$ and $\mathrm{Pt}-\mathrm{K} / \mathrm{Al}_{2} \mathrm{O}_{3}$ DPNR Catalysts. Top Catal 52:2041-2046

26. Gálvez ME, Ascaso S, Moliner R, Lázaro MJ (2013) Influence of the alkali promoter on the activity and stability of transition metal 
$(\mathrm{Cu} \mathrm{Co}, \mathrm{Fe})$ based structured catalysts for the simultaneous removal of soot and $\mathrm{NO}_{\mathrm{x}}$. Top Catal 56:493-498

27. Doggali P, Kusaba H, Rayalu S, Teraoka Y, Labhsetwar N (2013) Bench scale experiments of diesel soot oxidation using $\operatorname{Pr}_{0.7}$ $\mathrm{Sr}_{0.2} \mathrm{~K}_{0.1} \mathrm{MnO}_{3}$ perovskite type catalyst coated on ceramic foam filters. Top Catal 56:457-461

28. Mizutani K, Takizawa K, Shimokawa H, Suzawa T, Ohyama N (2013) A Novel $\alpha-\mathrm{Al}_{2} \mathrm{O}_{3}$ diesel particulate filter with alkali metalbased catalyst for diesel soot oxidation. Top Catal 56:473-476

29. Ito S, Kurosawa H, Akashi K, Michiue Y, Watanabe M (1996) Crystal structure and electric conductivity of $\mathrm{K}^{+}-\beta$-ferrite with ideal composition $\mathrm{KFe}_{11} \mathrm{O}_{17}$. Solid State Ionics 86:745-750

30. Kotarba A, Barański A, Hodorowicz S, Sokołowski J, Szytuła A, Holmlid L (2000) Stability and excitation of potassium promoter in iron catalysts-the role of $\mathrm{KFeO}_{2}$ and $\mathrm{KAlO}_{2}$ phases. Catal Lett 67:129-134

31. Luo J, Zhang Q, Huang A, Suib SL (2000) Total oxidation of volatile organic compounds with hydrophobic cryptomelane-type octahedral molecular sieves. Microporous Mesoporous Mater 35:209-216

32. Ching S, Landrigan JA, Jorgensen ML, Duan NG, Suib SL, OYoung CL (1995) Sol-Gel synthesis of birnessite from $\mathrm{KMnO}_{4}$ and simple sugars. Chem Mater 7:1604-1606

33. Jakubek T, Kaspera W, Legutko P, Stelmachowski P, Kotarba A (2015) Surface versus bulk alkali promotion of cobalt-oxide catalyst in soot oxidation. Catal Commun 71:37-41

34. Ross CR, Rubie DC, Paris E (1990) Rietveld refinement of the high-pressure polymorph of $\mathrm{Mn}_{3} \mathrm{O}_{4}$. Am Mineral 75:1249-1252

35. Vicat J, Fanchon E, Strobel P, Tran Qui D (1986) The structure of $\mathrm{K}_{1.33} \mathrm{Mn}_{8} \mathrm{O}_{16}$ and cation ordering in hollandite-type structures. Acta Crystallogr B 42:162-167

36. Gaillot AC, Lanson B, Drits VA (2005) Structure of birnessite obtained from decomposition of permanganate under soft hydrothermal conditions. 1. Chemical and structural evolution as a function of temperature. Chem Mater 17:2959-2975

37. Iizumi M, Koetzle TF, Shirane G, Chikazumi S, Matsui M, Todo $\mathrm{S}$ (1982) Structure of magnetite $\left(\mathrm{Fe}_{3} \mathrm{O}_{4}\right)$ below the Verwey transition temperature. Acta Crystallogr B 38:2121-2133

38. Tomkowicz Z, Szytuła A (1977) Crystal and magnetic structure of $\mathrm{KFeO}_{2}$. Phys Chem Solids 38:1117-1123

39. Shaheen WM, Ali AA (2001) Characterization of solid-solid interactions and physico-chemical properties of copper-cobalt mixed oxides and $\mathrm{Cu}_{\mathrm{x}} \mathrm{Co}_{3-\mathrm{x}} \mathrm{O}_{4}$ spinels. Mater Res Bull 36:1703-1716

40. Butel M, Gautier L, Delmas C (1999) Cobalt oxyhydroxides obtained by 'chimie douce' reactions: structure and electronic conductivity properties. Solid State Ionics 122:271-284
41. Ren L, Zhou W, Wang Y, Meng M, Wu S, Li S (2014) Magnetic properties of $\mathrm{Mn}_{3} \mathrm{O}_{4}$ film with a coexistence of two preferential orientations. J Appl Phys 116:023906

42. Iyer A, Del-Pilar J, King' ondu CK, Kissel E, Garces HF, Huang H, El-Sawy AM, Dutta PK, Suib SL (2012) Water oxidation catalysis using amorphous manganese oxides, octahedral molecular sieves (OMS-2), and octahedral layered (OL-1) manganese oxide structures. J Phys Chem C 116:6474-6483

43. Julien C, Massot M, Hadjean R, Franger S, Bach S, PereiraRamos J-P (2003) Raman spectra of birnessite manganese dioxides. Solid State Ionics 159:345-356

44. Lin J-F, Wu J, Zhu J, Mao Z, Said AH, Leu BM, Cheng J, Uwatoko Y, Jin C, Zhou J (2014) Abnormal elastic and vibrational behaviors of magnetite at high pressures. Sci Rep 4:6282

45. Kreisel J, Lucazeau G, Vincent H (1998) Raman spectra and vibrational analysis of $\mathrm{BaFe}_{12} \mathrm{O}_{19}$ hexagonal ferrite. J Solid State Chem 137:127-137

46. Hadjiev VG, Iliev MN, Vergilov IV (1988) The Raman spectra of $\mathrm{Co}_{3} \mathrm{O}_{4}$. J Phys C 21:L199-L201

47. Gnana Sundara Raj B, Asiri AM, Wu JJ, Anandan S (2015) Synthesis of $\mathrm{Mn}_{3} \mathrm{O}_{4}$ nanoparticles via chemical precipitation approach for supercapacitor application. J Alloy Compd 636:234-240

48. Iyengar SJ, Joy M, Maity T, Chakraborty J, Kotnala RK, Ghosh S (2016) Colloidal properties of water dispersible magnetite nanoparticles by photon correlation spectroscopy. RSC Adv 6:14393-14402

49. Legutko P, Jakubek T, Kaspera W, Stelmachowski P, Sojka Z, Kotarba A (2014) Soot oxidation over K-doped manganese and iron spinels-How potassium precursor nature and doping level change the catalyst activity. Catal Commun 43:34-37

50. Kaczmarczyk J, Zasada F, Janas J, Indyka P, Piskorz W, Kotarba A, Sojka Z (2016) Thermodynamic Stability, Redox Properties and Reactivity of $\mathrm{Mn}_{3} \mathrm{O}_{4}, \mathrm{Fe}_{3} \mathrm{O}_{4}$, and $\mathrm{Co}_{3} \mathrm{O}_{4}$ Model Catalysts for $\mathrm{N}_{2} \mathrm{O}$ Decomposition: Resolving the Origins of Steady Turnover. ACS Catal. doi:10.1021/acscatal.5b02642

51. Fino D, Bensaid S, Piumetti M, Russo N (2016) A review on the catalytic combustion of soot in Diesel particulate filters for automotive applications: from powder catalysts to structured reactors. Appl Catal A 509:75-96

52. Rico Pérez V, Bueno-López A (2015) Catalytic regeneration of diesel particulate filters: comparison of Pt and CePr active phases. Chem Eng J 279:79-85

53. Modén B, Da Costa P, Ki Lee D, Iglesia E (2002) Transient studies of oxygen removal pathways and catalytic redox cycles during NO decomposition on Cu-ZSM5. J Phys Chem B 106:9633-9641 